\title{
Culture in Language Teaching
}

\section{A course design for teacher trainees}

\author{
Gabriella KOVÁCS
}

Department of Applied Linguistics

Faculty of Technical and Human Sciences, Târgu-Mureş

Sapientia Hungarian University of Transylvania

kovagabi@yahoo.com

\begin{abstract}
Learning a language means also the study of a different culture. This study focuses on the introduction of the topic of culture in language teaching into the curriculum of the subject Language Teaching Methodology for teacher trainees studying at Translation And Interpreting Studies, Sapientia Hungarian University of Transylvania, Faculty of Technical and Human Sciences, TârguMureş. This topic has not been treated separately so far, it has only been discussed implicitly, included in other topics. But we believe that future teachers should have a more thorough theoretical and practical training in terms of what incorporating culture into language teaching implies. For this purpose, we are going to examine and discuss some of the recommendations and principles stated in the specialized literature regarding culture in foreign language teaching and reflect on what the ideal content of a course related to the teaching of this skill should be.
\end{abstract}

Keywords: culture, language teaching, methodology course, teacher training

\section{Introduction}

The role and status of culture in language teaching has always been a challenging issue for teachers. Their conception and opinion may be very different regarding the meaning of culture and the possibilities of incorporating cultural content into the language teaching process. These differences can result from their previous experience as language learners, from what they have learnt along their training process, and from the various possibilities they have had to come into direct contact with the target culture. The cultural content taught in language classes may also be influenced by the extent of differences between the native and target cultures.

Generally, in language teaching, the emphasis is on the development of four separate skills: listening comprehension, reading comprehension, writing, and 
speaking. However, language teachers and scholars often refer to a fifth skill, which is culture. It is difficult to imagine language teaching without referring in one way or another to the target culture; therefore, culture has always been present in the teaching process. But what does this skill imply and how should it be included into the teaching-learning process? Compared to grammar or vocabulary, culture is more difficult to define; therefore, it is not clear what and how should be taught.

However, we strongly believe that some principles, recommendations, and practical ideas regarding the introduction of cultural content must be included in the curriculum of language teaching methodology. Teacher trainees need to develop a theoretical and practical awareness of what culture means and in what forms it may be present in the language classroom.

This study focuses on discussing what should be taught about culture in language teaching, a topic in the curriculum of Language Teaching Methodology, designed for students of Translation and Interpreting Studies, Sapientia Hungarian University of Transylvania, Faculty of Technical and Human Sciences, Târgu-Mureş. This topic has not been treated separately so far, but it has been included in the discussion and practice of other topics - generally included in methodology courses such as the short history of language teaching (different language teaching methods); the communicative approach; teaching pronunciation, grammar, vocabulary, and pragmatic elements; developing reading comprehension, writing, listening comprehension, and speaking skills; learning styles and strategies; classroom management and teacher-student interaction; material development; evaluation.

This article is primarily a non-exhaustive study of the literature related to culture in language teaching. Our main purpose is to outline the main concepts, principles, and approaches regarding culture in language teaching (in particular, English language teaching because the majority of our students are future English teachers) and to present some practical ideas and strategies which teacher trainees may find useful in their future career.

\section{Definition of culture}

The definition of culture itself has been a much debated issue among scholars along the centuries. We do not intend to enter into details regarding the history and alterations of definitions; instead, we present the definition given in The New Encyclopedia Britannica, Micropaedia, which seems to encompass all the elements that may be part of this concept. It states that culture is:

The integrated pattern of human knowledge, belief and behaviour. Culture thus defined consists of language, ideas, beliefs, customs, taboos, codes, institutions, tools, techniques, works of art, rituals, ceremonies, and 
other related components; and the development of culture depends upon man's capacity to learn and to transmit knowledge to succeeding generations. (p. 784)

The definition is followed by a brief treatment of the term, where it is stated that there is a large number of definitions given by social scientists and anthropologists.

Every human society has its own particular culture, or sociocultural system, which overlaps to some extent with other systems. Variation among sociocultural systems is attributable to physical habitats and resources; to the range of possibilities inherent in various areas of activity such as language, rituals and customs, and the manufacture and use of tools; and to the degree of social development. The attitudes, values, ideas, and beliefs of the individual are greatly influenced by the culture in which he lives, and an individual may, of course, live in or travel among several different cultures. (Ibid.)

The New Encyclopedia Britannica, Macropaedia dedicates a total of 19 pages to the explanation of the concept, definitions and types of culture, and the different approaches to the study of culture.

Obviously, future language teachers are not expected to be experts in the theory of culture, but they have to be aware of what this term encompasses and especially what it means related to the study of a foreign language. They should know that culture cannot be taught simply through a few explicit lessons about some specific customs, holidays, songs, or works of literature. It is a much broader concept than that, implicitly present in the appropriate use of different linguistic forms as well. Language and culture are inseparable, as it is pointed out by Kramsch:

In the dyad "language and culture", language is not a bunch of arbitrary linguistic forms applied to a cultural reality that can be found outside of language, in the real world. Without language and other symbolic systems, the habits, beliefs, institutions, and monuments that we call culture would be just observable realities, not cultural phenomena. To become culture, they have to have meaning. It's the meaning that we give to foods, gardens and ways of life that constitute culture. (Kramsch 2013: 62)

\section{Big $C$ culture, little $c$ culture}

Language teachers in Romania who are now in their 40s studied languages in a very different way in their school years from the way languages are taught 
and studied now. Before 1989, language teaching used to be heavily influenced by the political ideology of the communist regime, while innovative ideas, developments, or new materials were inaccessible. It took almost a decade to change the well-established mentality and practices and exchange them with the modern principles and practice of communicative language teaching. This, in fact, also meant a change from a grammar-translational teaching style concentrating on some carefully chosen big $C$ culture content to a more open interpretation and understanding of culture and the admission of more little $c$ culture into the curriculum, followed by an even wider approach, the acceptance of the concept of interculturality.

But what is the difference between big C culture and little $c$ culture? According to Kramsch, what we now call big $C$ culture is a humanistic concept, a characteristic of the educated middle class, and it is in fact the result of the study of literature and arts, taught in schools. If, together with the target language, we also teach about the history, literature, arts, and institutions of the respective community, the language will be embedded into "the reassuring continuity of a national community that gives it meaning and value". Language learners may belong to a culture with different values and moral codes, and this may make it difficult for them to understand the target culture's notions of the "good" and "proper" way of life. Therefore, it may seem more comfortable to seek refuge in literary fiction or cultural stereotypes. And indeed, as an example to illustrate Kramsch's view, probably this is why most language teachers in Romania are still trained in departments of foreign language and literature, where the study of literature has a dominant status. This approach, as Kramsch suggests, "is a reminder that language study was originally subservient to the interests of philologists and literary scholars, not anthropologists or sociologists" (2013: 65).

Communicative language teaching has brought an important change regarding the concept of culture, and a more pragmatic approach, culture as a way of life has been adopted. As Kramsch states, this little $c$ culture focuses mainly on everyday life, on social interaction and communication, including behaviour, beliefs, values, eating, dwelling, and talking habits. Most studies conducted about the cultural component in the language teaching and learning process concentrated on "cross-cultural pragmatics and the sociolinguistic appropriateness of language use in its authentic cultural context". However, she also draws attention to the traps of teaching little $c$ culture.

To study the way native speakers use their language for communicative purposes, the convention "one language = one culture" is maintained and teachers are enjoined to teach rules of sociolinguistic use the same way they teach rules of grammatical usage (i.e., through modelling and role-playing). Even though everyday cultural practices are as varied as 
a native speaker's use of language in everyday life, the focus is on the typical, sometimes stereotypical, behaviours, foods, celebrations and customs of the dominant group or of that group of native speakers that is the most salient to foreign eyes. (2013: 66)

Alptekin (2002) also pinpoints the utopianism of little $c$ culture - the concept referring to characteristic ways of thinking and behaving of a target language community and their everyday customs -, highlighting its monolithic perception of culture and language.

\section{Culture and language teaching - changing perspectives}

Language teachers must always be mediators between cultures, the primary sources of the target culture for their students.

Cultural content and cultural awareness has varied along the history of language teaching and within the different methods. According to Bárdos (2004), a currently fashionable wider interpretation of culture, meaning that culture is everything that is created, made, or touched by humans, may become relevant from the point of view of planning language teaching. This wide interpretation has several advantages, namely that teachers can freely choose from various topics and phenomena which can easily meet these requirements.

The recommendations of the European Council and the Common European Framework of Reference for Languages: Learning, Teaching, Assessment (2002) reflect this wide interpretation of the term. The projects and proposals of the European Council regarding language teaching showed a significant change of perspective in the 1970s, states Bárdos. This change was influenced by research results in the domains of pragmatics, psycholinguistics, sociolinguistics, and social psychology. In a modern, multicultural world, foreign language speakers have to be able to use the language according to the norms of the respective community, and they have to be aware of what may, may not, or should not be said as part of their language behaviour. Speakers must take into consideration the situation, the circumstances, the topic, the expected level of formality, their partner's level of knowledge, and the culture-sensitive scenarios. The development of genuine and accurate language behaviour and personal style is a result of such careful approach and thorough selection (Bárdos 2005: 149-150).

As it is stated in the Common European Framework of Reference for Languages: Learning, Teaching, Assessment, the language user's ability to communicate is shaped and influenced by all human competences, and therefore all these may be regarded as aspects of communicative competence. General competences include declarative knowledge (knowledge of the world, sociocultural knowledge, and 


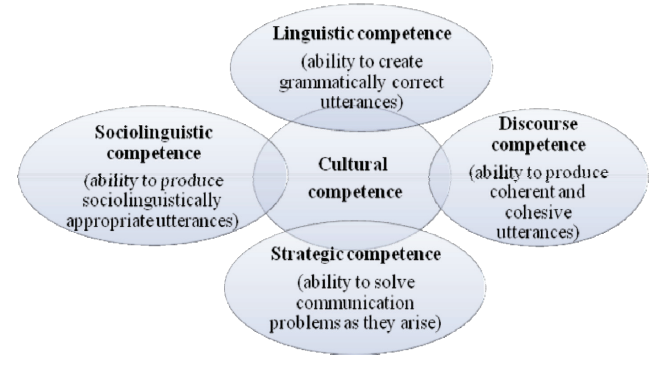

Figure 1. The place of cultural competence in communicative competence (Bárdos 2004: 151)

intercultural awareness), skills and know-how (practical and intercultural skills and know-how), existential competence, and the ability to learn (language and communication awareness, general phonetic awareness and skills, study skills, and heuristic skills). Communicative language competences include linguistic competences (lexical, grammatical, semantic, phonological, orthographic, and orthoepic), sociolinguistic competences (linguistic markers of social relations, politeness conventions, expressions of folk wisdom, register differences, dialect, and accent), and pragmatic competences (discourse competence and functional competence) (CEFR 2002: 101-130). Language teachers and researchers widely believe that there is another competence, the cultural one, which is present in one way or another in all the above mentioned categories. Bárdos, for instance, added culture as a fifth competence to a model developed by Canale and Swain (1980). In his interpretation, culture is present in and is part of all the other competences.

Several other statements and viewpoints have been formulated regarding the status, importance, and content of culture in language teaching, showing the complexity of the issue. Some frequently quoted interpretations belong to Rivers (1981, 1987), Byram (1989), and Seelye (1993). According to Rivers, "we must focus on both appropriate content and activities that enable students to assimilate that content. Activities should encourage them to go beyond fact, so that they begin to perceive and experience vicariously the deeper levels of the culture of the speakers of the language" (1981: 314). She also states that in the design of these activities teachers should concentrate to choose the best approach and procedures that can lead students to "successful cross-cultural encounters" (1987: 12). Byram draws attention to the problem of skill-centric language teaching, which tends to neglect the cultural elements: "foreign language teaching is, both in my experience as learner and teacher and in my pedagogic philosophy, as education, an emancipation from the confines of one's native habitat and culture; the current emphasis on language teaching as skill training is apt to lose that from sight" (Byram 1989: viii). Seelye's statement confirms this 
problem: "learning a language in isolation of its cultural roots prevents one from becoming socialized into its contextual use. Knowledge of linguistic structure alone does not carry with it any special insight into the political, social, religious, or economic system. Or even insight into when you should talk and when you should not" (1993: 10).

As it emerges from these citations, the culture of the people who use the target language as native speakers cannot and must not be ignored in the language teaching and learning process. We cannot deny the importance of native speaker norms; however, in case of some international languages used in several countries all over the world, for example, English, the issue becomes more complicated. Alptekin (2002) points out that "communicative competence, with its standardized native speaker norms, is as utopian as the notion of the idealized native speaker-listener" (p. 59), it "fails to reflect the lingua franca status of English" (Id.: 60), and "circumscribes learner and teacher autonomy" (Id.: 61). Some languages, for example, English, have several dialects; hence it is impossible to claim that there is only one appropriate and correct way to use them. According to the data presented by Ethnologue, English is spoken by approximately 983,522,920 people in the world, and from those 371,959,910 speak it as a native language and $611,563,010$ as a second language. It is used in 97 countries with different status such as national language, the language used for wider communication, national working language, or educational language. English is the language of international communication, and the number of nonnative speakers of English exceeds by far the number of native speakers. The possibility of interaction in English between two non-native speakers becomes much higher than between a native and a non-native speaker. This is why Alptekin questions the relevance of the conventions of British politeness or American informality to, for example, some Japanese and Turks when doing business in English; or the relevance of discourse samples, such as American advertisements or British railway timetables, to industrial engineers from Egypt and Romania working on a technical project in English. He believes that a new approach is needed in language teaching, which takes into account the international status of English and focuses on the necessity of instructional materials that may help students in becoming "successful bilingual and intercultural individuals who are able to function well in both local and international settings" (2002: 63).

\section{5. "Third place" or "third culture"}

Bianco, Crozet, and Liddicoat (1999) emphasize the importance of developing intercultural competence through language teaching. They believe that such an approach offers students better opportunities of unmediated, direct experience 
and encounter with other cultures. Intercultural interaction is not a question of becoming assimilated into the target culture's frame nor is it a question of preserving the learner's own frame; it is rather an endeavour of finding a bridge between these two places, of finding a "third place". Thus, the language learner is not a passive observer but can actively experience and explore the other culture. Bianco et al. distinguish three paradigms in the history of language teaching, regarding different approaches to teaching culture. The first one is the traditional approach, which concentrates mainly on the teaching of literature, with minimal expectations of using the target language in order to interact with representatives of the target language and culture. This paradigm began to be replaced by the "Culture studies" approach in the 1970s, where culture meant mainly learning a body of knowledge about the history, institutions, and geography of the target language country. The third paradigm, the culture as practices approach became popular in the 1980s, and it "sees culture as a collective way of acting through language" (p. 9). The language learners are mainly observers and interpreters of the actions and words of interlocutors from the target culture, but they tend to remain within their own cultural paradigm. In this approach, culture is represented as relatively homogeneous and static, which may lead to the formation of stereotypes.

The fourth paradigm is intercultural language teaching, which, according to Bianco et al., should be the new paradigm in the future. Its approach differs significantly from the previous ones because it embraces a new understanding of the nature of cross-cultural encounters and of the relations between culture and language. At the end of the 1990s, the authors believe that the Communicative Approach, although a revolution in language teaching, could still not fulfil the expected improvements in the development of cross-cultural understanding and intercultural competence. Culture expressed in spoken or written language and the way language shapes human relationships and interactions is not as easily accessible for examination in the language classroom as grammar or different functions of language. It is important to offer the possibility to language learners to experience and understand how culture and language shape people's world views. The three fundamental aspects of intercultural language teaching include the teaching of a linguaculture (links between language and culture), a comparison of the students' native language and culture with the target language and culture, and intercultural exploration (a third place between two cultures).

Kramsch (1993) also discusses and examines the issue of culture in language education through the concept of creating a third place between two cultures, and she points out that "[at] the intersection of multiple native and target cultures, the major task of language learners is to define for themselves what this 'third place' that they have engaged in seeking will look like, whether they are conscious of it or not" (p. 233). She also calls this third place the "third culture" of language learners, a neutral state which allows learners to reflect on the target language 
culture and also on their own. This term is a metaphor, created to avoid the dichotomy of native versus non-native speakers and some dualities of language education such as first versus second language or first versus second culture. Kramsch (2009) attributes three characteristics to this third culture or third place. It is a popular culture because in this third culture the learner is in a controversial place, trying to create meanings on the edges of or in the gaps between two cultures; therefore, language teachers embracing the idea of this third culture should create possibilities for playfulness through role-play or simulation, for the invention of hybrid, fictional identities in order to help learners find their own meaning. It is also a critical culture, encouraging critical thinking regarding the cultural content of language teaching, promoting resistant reading of textbooks, looking beyond the dominant cultural beliefs in order to question prevailing views. And, finally, it is an ecological culture because a language teaching methodology which adopts the idea of third culture is sensitive to the context and responds to the demands of the environment. It may use any suitable and available methods such as communicative activities, vocabulary memorization, learning poems by heart; real-world tasks, dictation, translation, transcription of written texts or audio-recordings; rereading, retelling, multiple interpretations of the same text, various ways of making meaning (verbal, visual, gestural, or even musical) and different modalities of expression (spoken, written, or electronic). "Bricolage is the name of the game", says Kramsch (p. 238).

Peterson and Coltrane (2003) highlight that cultures cannot be considered monolithic, and students need to be aware of this. In any culture, different behaviours may be acceptable for any kind of interaction. Students must be given the opportunity to explore and observe such interactions, reflect on them, and try to discover their own voices in the speech community of the target language. Moeller and Nugent (2014) also emphasize that intercultural competence should be an integral part of foreign language curriculums.

When intercultural competence is an integral part of the language classroom, learners experience how to appropriately use language to build relationships and understandings with members of other cultures. They can examine their own beliefs and practices through a different lens, negotiate points of view different from their own, and gain an insider's perspective of another culture. (Moeller \& Nugent 2014: 14)

\section{Culture in the language classroom}

In this section of our study, we present some useful ideas and strategies for introducing culture in the language classroom. These practical approaches may 
be used as topics for discussion and practice in the seminars of language teaching methodology.

The first and, in our opinion, the most important issue we would like to discuss is the use of authentic materials. As Peterson and Coltrane (2003) state, materials from authentic sources may help to offer authentic cultural experiences to language learners. These may include television shows, news broadcasts, films, the use of different websites or printed materials such as travel brochures, photographs, newspapers, magazines, restaurant menus, etc. The materials obtained from these sources can be adapted to the proficiency level of the students - even beginners may watch or listen to authentic visual or audio materials and focus on different cultural conventions, for example, greetings. The students can be given different tasks to perform while watching or listening, such as completing diagrams, charts, or outlines. After watching or listening to the relevant parts, discussions of cultural norms, characteristics and values of the target language community should follow, which may also include non-verbal behaviours such as eye contact, gestures, mimicry, or distance between speakers. Learners should be encouraged to describe the observed behaviours and propose and try out strategies for communication in the target language.

Another important issue is the efficient introduction and practice of such culture-specific elements as collocations, idioms, or proverbs. A collocation, as defined by the English Oxford Living Dictionaries in linguistics, means "the habitual juxtaposition of a particular word with another word or words with a frequency greater than chance". Collocations can seem difficult to remember for language learners because students may try to translate meanings literally from their native language instead of using the appropriate collocation from the target language. Therefore, these structures must be explained and practised in the classroom. For example, English collocations such as do the dishes, make friends, or take a nap cannot be translated literally into Hungarian, wherefore Hungarian students must practise and memorize these expressions.

Idioms pose an even greater challenge. In the Longman Dictionary of Language Teaching and Applied Linguistics, the term idiom is defined as "an expression which functions as a single unit and whose meaning cannot be worked out from its separate parts". For example: she washed her hands of the matter means that she refused to have anything more to do with the matter (Richards \& Schmidt 2010: 270). Irujo (1986) gives three possible explanations for the problems that non-native speakers of English encounter regarding idioms: non-literalness, exposure to idioms, and correct use. By non-literalness, she means that their meaning is different from what they say literally. "For example, the idiomatic meaning of he spilled the beans has nothing to do with beans or with spilling in its literal sense. Most idioms also have literal counterparts, which makes them 
even harder to learn” (p. 236). In the case of language learners, non-literalness and possible literal counterparts might create difficulties in recognizing or properly using an idiom. Regarding the exposure to idioms, the problem in fact is non-exposure or not enough exposure because native speakers tend to use simplified language when speaking to second-language learners or non-native speakers. "Thus learner's exposure to idioms appears mainly in non-interactive situations, where there is no opportunity for negotiation of meaning, rather than in interactive situations which allow learners to clarify meaning and receive feedback on use" (p. 237). Regarding correct use, Irujo draws attention to the following factors: "idioms vary in formality from slang (you got it) and colloquialisms (he kicked the bucket) to those which can be used in formal situations (run the risk)" and the fact that "many idioms have grammatical constraints" (p. 237).

A proverb, defined by the English Oxford Living Dictionaries as "a short, well-known pithy saying, stating a general truth or piece of advice", again may or may not have counterparts in the language learner's native language. Peterson and Coltrane (2003) recommend that the introduction of proverbs in the target language should include the discussion of differences and similarities to proverbs in the students' native language. They believe that "using proverbs as a way to explore culture also provides a way to analyse the stereotypes about and misperceptions of the culture, as well as a way for students to explore the values that are often represented in the proverbs of their native culture" (p. 2).

Role-plays or simulations can be useful in practising different culturally appropriate language forms and behaviours. The use of different culture-specific realia may also help in finding out more about the everyday life and routines characteristic to the target language culture. Realia in language teaching refers to "actual objects and items which are brought into a classroom as examples or as aids to be talked or written about and used in teaching" (Richards \& Schmidt 2010: 485). Objects such as photographs, kitchen tools, articles of clothing, souvenirs, musical instruments, or even food may be used to discuss their cultural relevance and plan various activities based on their cultural or historical importance.

We believe that future language teachers should be trained to formulate concrete objectives regarding the cultural content of the curriculum and develop specific cultural activities according to their objectives. However, they cannot be expected to design all their teaching materials themselves. They must develop a critical approach to available, recommended, and accredited textbooks which may be used in the language classroom and choose those which offer the best materials not only for the development of the four "traditional" skills (reading, listening, writing, and speaking) but also of the "fifth" skill, culture. 
English is an international language, which must be taken into consideration when selecting the cultural content for English language courses. The international use of the language must also be reflected in the textbooks, and the "fifth skill" should be developed with the acceptance of an intercultural approach. Cortazzi and Jin (1999) and McKay (2000) recommend three categories for analysing the cultural content of English textbooks: the source culture (the learner's native culture), the target culture (for example, British, American, or Australian culture), and the international target culture (varieties of the target culture from all over the world, characteristic of the countries where English is spoken). It is important to find textbooks which deal with these three categories in a balanced way. In teacher training, future teachers may be helped to develop critical thinking and make responsible choices through projects and activities aiming for the analysis, discussion, and comparative study of the cultural content of accredited textbooks.

\section{Conclusions}

In this study, we have conducted a non-exhaustive review of the literature related to culture in language teaching. Our main purpose was to outline the main concepts, principles, and approaches regarding this issue in order to introduce the topic of culture in language teaching into the curriculum of the subject Language Teaching Methodology for language teacher trainees studying translation and interpreting at Sapientia Hungarian University of Transylvania.

Based on the recommendations of the consulted literature, we can conclude that the following ideas should definitely be included in the theoretical part of the course material: the concept and definition of culture; the importance of cultural content in language teaching, a historical overview of the status and attitude towards culture along the history of language teaching; the difference between big $C$ and little $c$ culture; the concepts "fifth skill" and "fifth competence"; the "third place" and "third culture" of the language learner; the concept and relevance of international language teaching.

In the seminars, more emphasis should be placed on the practical aspects of dealing with cultural content in the classroom. Such activities may involve the selection and use of authentic materials (for example, television shows, news broadcasts, films, the use of different websites or printed materials such as travel brochures, photographs, newspapers, magazines, restaurant menus); the design and choice of activities and exercises for teaching culture-specific elements as collocations, idioms, proverbs, or realia; planning and facilitating role-plays or simulations related to culturally acceptable and appropriate 
language use and behaviour; discussion and comparative study of the cultural content of accredited textbooks.

\section{References}

Alptekin, Cem. 2002. Towards intercultural communicative competence in ELT. ELT Journal 56(1): 57-64.

Bárdos, Jenő. 2004. Kulturális kompetencia az idegen nyelvek tanításában [Cultural competence in foreign language teaching]. In: Bárdos, Jenő, Nyelvpedagógiai tanulmányok [Studies in language pedagogy]. Pécs: Iskolakultúra. 142-157. 2005. Élő nyelvtanítás-történet [A living history of language teaching]. Budapest: Nemzeti Tankönyvkiadó.

Lo Bianco, Joseph-Liddicoat, Anthony J.-Crozet, Chantal. 1999. Introduction: intercultural competence: from language policy to language education. In: Lo Bianco, Joseph-Liddicoat, Anthony J.-Crozet, Chantal (eds), Striving for the third place: intercultural competence through language education. Melbourne, Language Australia. 1-17.

Byram, Michael. 1989. Cultural studies in foreign language education. Clevedon: Multilingual Matters.

Canale, Michael-Swain, Merill. 1980. Theoretical bases of communicative approaches to second language teaching and testing. Applied Linguistics 1: $1-47$.

Cortazzi, Martin-Jin, Lixian. 1999. Cultural mirrors: materials and methods in the EFL classroom. In: Hinkel, Eli (ed.), Culture in second language teaching and learning. Cambridge: Cambridge University Press. 196-220.

Irujo, Suzanne. 1986. A piece of cake: learning and teaching idioms. ELT Journal 40(3). Oxford: Oxford University Press.

Kramsch, Claire. 1993. Context and culture in language teaching. Oxford: Oxford University Press.

2009. Third culture and language education. In: Cook, Vivien-Wei, Li. (eds), Contemporary applied linguistics. London: Continuum. 233-254.

2013. Culture in foreign language teaching. Iranian Journal of Language Teaching Research 1(1): 57-78.

McKay, Sandra Lee. 2000. Teaching English as an international language: implications for cultural materials in the classroom. TESOL Journal 9(4): 7-11.

Moeller, Aleidine Kramer-Nugent, Kristen. 2014. Building intercultural competence in the language classroom. In: Dhonau, Stephanie (ed.), Unlock the gateway to communication. Central States Conference Report. 1-18. (Retrieved 
from: http://digitalcommons.unl.edu/cgi/viewcontent.cgi?article=1160\&conte $\mathrm{xt}=$ teachlearnfacpub).

Peterson, Elizabeth-Coltrane, Bronwyn. 2003. Culture in second language teaching. ERIC Clearinghouse on Languages and Linguistics, EDO-FL-03-09. (Retrieved from: https://media.startalk.umd.edu/workshops/2009/SeattlePS/ sites/default/files/files/CAL_\%20Digests_\%20Culture\%20in\%20Second \% 20 Language\% 20Teaching.pdf).

Rivers, Wilga. 1981. Teaching foreign language skills. Chicago: University of Chicago Press.

1987. Interaction as the key to teaching language for communication. New York: Cambridge University Press.

Seelye, H. Ned. 1993. Teaching culture: strategies for foreign language educators. $3^{\text {rd }}$ ed. Lincolnwood: National Textbook Company.

\section{Internet sources}

https://en.oxforddictionaries.com

https://www.ethnologue.com/

\section{Encyclopaedias and dictionaries}

Richards, Jack. C.-Schmidt, Richard. W. 2010 [1985]. Longman dictionary of language teaching and applied linguistics. London: Pearson.

The New Encyclopaedia Britannica, Volume 16, Macropaedia. 1992. 15 ${ }^{\text {th }}$ ed. Chicago: The University of Chicago.

The New Encyclopaedia Britannica, Volume 3, Micropaedia. 1992. 15 ${ }^{\text {th }}$ ed. Chicago: The University of Chicago. 